\title{
Zaufanie do lekarzy oraz przekonania osób starszych na temat efektywności medycyny w walce $z$ chorobami nowotworowymi
}

\section{Trust in doctors, and the beliefs of older people about the effectiveness of medicine in the fight against cancer}

\author{
Małgorzata Synowiec-Piłat ${ }^{1 凶}$, Beata Zmyślona², Anna Pałęga ${ }^{3}$ \\ ${ }^{1}$ Uniwersytet Medyczny im. Piastów Śląskich we Wrocławiu, Zakład Humanistycznych Nauk Lekarskich, ul. Mikulicza-Radeckiego 7, 50-368 Wrocław \\ ${ }^{2}$ Uniwersytet Ekonomiczny we Wrocławiu, Katedra Statystyki, ul. Komandorska 118/120, 53-345 Wrocław \\ 3Wyższa Szkoła Zarządzania „Edukacja” we Wrocławiu, Katedra Pedagogiki, ul. Krakowska 56-62, 50-425 Wrocław \\ $\triangle$ m.synowiecpilat@gmail.com
}

\begin{abstract}
Introduction: Poland is one of the countries with the highest rates of cancer mortality. Throughout Europe and the US, more than $60 \%$ of the total cancer incidence is in persons 65 years and older. In the fight against cancer, not only large-scale actions are necessary, but also the improvement of the physician-patient relationship itself. An important part of this relationship is patient's trust.

In this article we present a study on seniors' level of trust in doctors and older people's beliefs about the effectiveness of medicine in the fight against cancer, as well as the influence of variables such as sex, economic status and education on the level of trust in the physician and medicine.

Materials and methods: In 2012, sociological research was conducted among 329 older people in Wrocław in Poland. Quota sampling was applied and a questionnaire with a high level of
\end{abstract}

standardization was used. We used available methods for categorical data analysis.

Results: Most of the respondents declared trust in doctors but to varying degrees. The level of trust in a doctor depends on income and education; $44.98 \%$ of respondents agreed with the statement that "modern medicine (...) can cope effectively with cancer". However, $55.02 \%$ of respondents disagreed with that. The type of declaration was correlated with the income of respondents.

Conclusions: The level of trust in physicians and medicine depends on socio-demographic variables that determine inequalities in health, such as age, economic situation and education. The results will be used to develop more effective health promotion and oncological prevention programmes targeting older people. Keywords: doctor-patient relationship; health and medical sociology; cancer; health beliefs.

\begin{abstract}
ABSTRAKT
Wstęp: Polska należy do krajów o najwyższych wskaźnikach umieralności na raka. Ponad 60\% zachorowań na raka w Europie i USA odnotowuje się u osób powyżej 65. r.ż. W walce z chorobami nowotworowymi niezbędne są nie tylko działania makrostrukturalne, lecz również poprawa samej relacji lekarz-pacjent. Ważnym elementem tej relacji jest zaufanie pacjenta.

W niniejszym artykule przedstawione zostały badania dotyczące zaufania osób starszych do lekarzy oraz ich przekonania na temat efektywności medycyny w walce $\mathrm{z}$ chorobami nowotworowymi, a także wpływ takich zmiennych jak płeć, status ekonomiczny i wykształcenie na poziom zaufania do lekarza i medycyny. Materiały i metody: Badania socjologiczne zrealizowano w 2012 r. we Wrocławiu wśród 329 starszych osób. Zastosowano próbę kwotową. Jako metodę zastosowano wywiad kwestionariuszowy o wysokim poziomie standaryzacji. Zastosowano dostępne metody analizy danych jakościowych.
\end{abstract}

Wyniki: Większość badanych deklaruje zaufanie do lekarza, ale w różnym stopniu. Poziom zaufania do lekarza zależny jest od dochodów i wykształcenia; $44,98 \%$ zgadza się ze stwierdzeniem, że „współczesna medycyna (...) skutecznie radzi sobie z leczeniem nowotworów”, natomiast 55,02\% respondentów nie zgadza się z tym stwierdzeniem. Istnieje zależność pomiędzy tym przekonaniem a wysokością dochodów badanych.

Wnioski: Poziom zaufania do lekarzy i medycyny jest zróżnicowany ze względu na zmienne społeczno-demograficzne wyznaczające nierówności w sferze zdrowia, tj. wiek, sytuację ekonomiczną i poziom wykształcenia. Uzyskane wyniki posłużą do wypracowania skuteczniejszych działań z zakresu promocji zdrowia i profilaktyki onkologicznej ukierunkowanych na osoby starsze.

Słowa kluczowe: relacja lekarz-pacjent; socjologia zdrowia i medycyny; choroby nowotworowe; przekonania zdrowotne.

\section{WSTĘP}

Jednym z dominujących współcześnie problemów zdrowotnych w Europie i USA są choroby nowotworowe. Wzrost zagrożenia nimi rośnie z wiekiem, co jest w znacznym stopniu konsekwencją postępującego procesu starzenia się społeczeństw rozwiniętych.
W populacji osób starszych obserwuje się obecnie 10-krotnie większe ryzyko zachorowania na raka w porównaniu z osobami poniżej 65. r.ż. [1]. Ponad 60\% zachorowań na choroby nowotworowe w Europie i USA odnotowuje się u osób powyżej 65. r.ż. [2, 3]. Także w Polsce 75\% zgonów na nowotwory złośliwe występuje po 60. r.ż. [4]. Dodatkowo warto zwrócić uwagę 
na fakt, iż Polska należy do krajów europejskich, w których odnotowano najwyższe wskaźniki umieralności na raka [5, 6].

W walce z chorobami nowotworowymi istotne jest nie tylko stałe podnoszenie jakości i dostępności do usług medycznych. Na szczególną uwagę zasługują także relacje osób zdrowych oraz pacjentów z lekarzami jako profesjonalistami. Jedną z najważniejszych wartości w socjologicznych i etycznych rozważaniach na temat relacji lekarz-pacjent jest zaufanie. Jest to istotny czynnik w procesie leczenia, ugruntowuje bowiem wiarę i nadzieję chorego na wyleczenie. Nabiera ono szczególnego znaczenia w przypadku chorób przewlekłych, a zwłaszcza nowotworowych, które dodatkowo obciążone są wysokim poziomem lęku $[7,8,9]$, silnym poczuciem zagrożenia życia lub niepełnosprawnością. W przypadku chorych na nowotwory istotne dla zaufania mogą być inne elementy niż u pacjentów cierpiących na pozostałe choroby przewlekłe. Wyniki badań pokazują, że osoby chore na nowotwór odznaczają się wyższym poziomem zaufania, nawet w porównaniu z zaufaniem do lekarzy w podstawowej opiece zdrowotnej $[10,11,12]$. W obliczu diagnozy raka zaufanie do onkologa wydaje się szczególnie istotne ze względu na zagrażający życiu charakter nowotworu [13]. Wyniki badań jakościowych sugerują, że u tych pacjentów potrzeba zaufania do onkologa jest silna [14]. Pacjenci muszą poradzić sobie z poważną diagnozą oraz obciążającym fizycznie i psychicznie leczeniem, co silnie wpływa na ich codzienne funkcjonowanie i przyszłość. Ponadto muszą oni zrozumieć złożone informacje i podejmować trudne decyzje medyczne. Ze względu na powyższe kwestie interpretacja i wyjaśnienie zaufania w przypadku chorych na nowotwór mogą różnić się od zaufania w innych populacjach pacjentów.

Zaufanie do lekarza lub jego brak jest efektem doświadczeń z dotychczasowych relacji lekarz-pacjent; jest wytwarzane, konstruowane w relacji lekarz-pacjent. W przypadku nowotworów czas leczenia jest długi i wymaga stałego kontaktowania się i współdziałania z personelem medycznym. Salmon i Young sugerują, że pacjenci z bardziej zagrażającymi chorobami mogą tworzyć bardziej pozytywne obrazy lekarzy, uzasadniając to tym, że „pacjenci subiektywnie konstruują wizerunek specjalisty w celu zaspokojenia własnych potrzeb w zakresie bezpieczeństwa i zależności" [12]. Ugruntowanie więzi społecznej między lekarzem a pacjentem pozwala na znalezienie wspólnej dla obu stron płaszczyzny emocjonalnej, co owocować może lepszą współpracą, a w konsekwencji przyczyniać się do optymalizacji procesu leczenia.

\section{Pojęcie zaufania do lekarza i medycyny}

Wyniki badań socjologicznych ułatwiają znalezienie odpowiedzi na pytanie, jakie czynniki społeczno-kulturowe wpływają na rozwój, podtrzymanie lub obniżenie zaufania w ramach opieki zdrowotnej. W analizach tych podkreśla się, że zaufanie ma fundamentalne znaczenie dla skuteczności relacji interpersonalnych. Życie bez ufności wymaga ciągłej czujności i przepełnione jest lękiem lub wymaga samotności [15]. Według Giddensa [16] zaufanie (trust) oparte jest na zawierzeniu, które równoważy niewiedzę lub brak informacji; jest to poleganie na osobach lub systemach abstrakcyjnych.
Zaufanie to przeświadczenie o niezawodności osoby lub systemu [17]. Autor podkreśla, że kondycję człowieka cechuje niepewność oraz poczucie zagrożenia. Na co dzień jednak, poprzez socjalizację, większość członków społeczeństwa jest w stanie uniknąć głęboko zakorzenionego niepokoju dzięki wykształceniu „podstawowego zaufania” wobec innych członków grupy oraz uznawanych za oczywiste sposobów życia. Zaufanie jest procesem iteracyjnym, budowanym podczas interakcji z innymi osobami. Ma silniejsze znaczenie w grupach pierwotnych ze względu na to, że wzajemne bliskie relacje dotkliwie piętnują przypadki naruszenia zaufania [18]. W przeważającej mierze ludzie zakładają, że inni postąpią w określonych sytuacjach zgodnie z obowiązującymi w grupie wartościami i normami, stosownie do swojej roli społecznej czy obowiązków. Dopuszcza się jednak świadomość, że ludzie naruszają zaufanie innych osób, nie postępują zgodnie z oczekiwaniami czy też oszukują. Zaufanie jest zawsze związane z przewidywaniem przyszłości [19], a jego utrzymanie wymaga pewnej równowagi między ryzykiem a ochronnym porozumieniem.

Są jednak okoliczności, w których ludzie są zobowiązani lub zmuszeni do zaufania osobom, nie wiedząc nic na ich temat lub mając zdawkową o nich wiedzę. Jak zauważa Giddens: „Obcy reprezentuje to, co nieznane (...) nieznaną wyznaczoną kulturowo przestrzeń, która oddziela to, co zewnętrzne, od «znajomego» świata ukształtowanego przez tradycje, z którymi identyfikuje się zbiorowość" [20]. Zaufanie staje się zatem niezbędnym zasobem, który pozwala jednostce poradzić sobie z obecnością obcych. Jednym z takich obszarów jest związek między lekarzem a pacjentem, który obejmuje także pacjentów z poważnymi i złożonymi chorobami, charakteryzujących się niepewnością. W tym przypadku niewłaściwie ulokowane zaufanie może mieć ogromne konsekwencje dla chorego. To, w jaki sposób pacjenci decydują o zaufaniu i testują jego wiarygodność, ujawnia ważną dynamikę relacji zaufania. Według Becka i wsp. [20] w potradycjonalistycznym społeczeństwie, w którym nie można przyjmować za pewnik wiarygodności innych osób, a zaufanie trzeba sobie nieustannie zdobywać, zasadne staje się przyjęcie strategii „aktywnego zaufania”, „otwierania się" na innych, okazywania uczuć. Nawet jeśli strategia tego rodzaju niesie ze sobą ryzyko, to może być jedyną szansą na wywołanie u innych poczucia obowiązku, imperatywu wiarygodności oraz nakazu wzajemności. Kwestię tę odnajdujemy również w relacji lekarz-pacjent. Warto zauważyć, że pacjent, chcąc współuczestniczyć w procesie leczenia jako partner, pozostaje jednocześnie nadal laikiem, który podlega władzy lekarza jako specjalisty. Powinien zaufać wiedzy i kompetencjom lekarza. Musi także ufać w to, że lekarz zechce wykorzystać swoje umiejętności na rzecz leczenia, że troskliwie się nim zajmie jako osobą cierpiącą i potrzebującą wsparcia.

Na podstawie socjologicznych badań oraz rozważań teoretycznych wyróżnić można dwa rodzaje zaufania w odniesieniu do opieki zdrowotnej: 1) interpersonalne, dotyczące interakcji poszczególnych pacjentów i pracowników służby zdrowia; 2) instytucjonalne, w odniesieniu do organizacji lub systemów opieki zdrowotnej [21, 22, 23]. Wyjaśnienie, w jaki sposób te dwa rodzaje zaufania są ze sobą powiązane, nie jest 
proste. W zrozumieniu złożoności relacji, które mają wpływ na zaufanie pacjenta zarówno do systemu medycznego, jak i poszczególnych lekarzy, może pomóc kompilacja teorii Giddensa i Luhmanna. Teorie te są cytowane w większości literatury poświęconej zaufaniu do opieki zdrowotnej [24, 25]. Pomimo że obie przedstawiają sprzeczne poglądy na temat tego, w jaki sposób rozwija się zaufanie, analizowane razem ukazują sieć powiązań, które przyczyniają się do zaufania do lekarzy i całego systemu medycznego. Luhmann twierdzi [19], że zaufanie do instytucji (systemu medycznego) jest konieczne, zanim jednostka (pacjent) nabędzie zaufania do przedstawicieli systemu (lekarzy). Luhmann uważa społeczeństwo za zbiór różnorodnych, wzajemnie oddziałujących na siebie systemów społecznych. Zaufanie instytucjonalne do medycyny jest w dużym stopniu zależne od zaufania jednostki do innych systemów społecznych (np. politycznych). Natomiast Giddens utrzymuje [17], że zaufanie interpersonalne do przedstawicieli systemów (lekarzy) jest konieczne, zanim powstanie zaufanie do instytucji (systemu medycznego). Zaufanie działa jako medium interakcji między systemami nowoczesnego społeczeństwa a przedstawicielami tych systemów. Zaufanie do systemów przyjmuje postać zobowiązań anonimowych (faceless commitment), które podtrzymują wiarę w działanie wiedzy w znacznym stopniu niedostępnej dla laika. Zaufanie do osób związane jest z zobowiązaniami imiennymi (facework commitment), od postawy „eksperta” (lekarza) i poziomu profesjonalizmu, sposobu zachowania, określonych aspektów osobowości, które wpływają na nasze wrażenie i oczekiwanie na nie. Giddens twierdzi, że zaufanie jest trwałe dzięki zobowiązaniom imiennym. Zaufanie do lekarza jest konieczne, aby mieć zaufanie do systemu medycznego. Punkty dostępowe (access points) to miejsca styczności pojedynczych laików (pacjentów) z przedstawicielami systemów (lekarzy). To wrażliwe miejsca systemów abstrakcyjnych, a także węzły, w których można podtrzymywać zaufanie lub je budować.

Zaufanie pacjenta do lekarza jest uważane za kluczowe dla dobrej jakości i skutecznej opieki medycznej [15]. Istnieje kilka definicji zaufania, ale zawsze uwzględniają one aspekt słabości pacjentów [26, 27, 28]. Hall i wsp. [29] definiują zaufanie jako optymistyczną akceptację wrażliwej (podatnej na zranienie) sytuacji (vulnerable situation), w której osoba ufająca uważa, że lekarz będzie dbać o jej interes. Calnan i Rowe [21,30] wyróżniają trzy czynniki, które utwierdzają zaufanie na poziomie relacji lekarz-pacjent: 1) wrażliwość związaną z zachorowaniem; 2) asymetrię informacji między obiema stronami; 3) niepewność co do intencji i kompetencji pracowników służby zdrowia. Poziom zaufania do systemu opieki zdrowotnej jest bardziej zbliżony do konceptualizacji Luhmanna, czyli confidence. Według Giddensa [17] zaufanie do abstrakcyjnych systemów jest ogólną cechą późnego społeczeństwa nowoczesnego, w którym obywatele nie mają dużo wiedzy na temat systemów eksperckich, takich jak rynki finansowe, złożone technologie czy struktury zarządzania, a zatem muszą w prosty sposób ufać, że te dobrze funkcjonują. W związku z tym obywatele muszą sami stawać się ekspertami i być bardziej refleksyjni w kwestii ich wyborów w opiece zdrowotnej.
Analizy empiryczne wskazują, że koncepcja zaufania w kontekście opieki zdrowotnej wydaje się obejmować zarówno kwestie kompetencji zawodowych (wiedza, umiejętności techniczne oraz społeczne/komunikacyjne), jak i zagadnienie dotyczące tego, czy działania personelu medycznego są podejmowane w najlepszym interesie pacjenta (uczciwość, poufność i troska, a także okazywanie szacunku) [15, 28]. Na podstawie badań jakościowych ustalono, że najczęściej wyróżnianym przez badanych aspektem zaufania była kompetencja interpersonalna, obejmująca opiekę, troskę i współczucie [15]. Wprawdzie kompetencje techniczne też uzyskały wysoki priorytet, ale często były oceniane przez pryzmat reputacji lekarza lub interpersonalnych znaków. Natomiast w badaniach nad zaufaniem do lekarzy w przypadku chorób nowotworowych ujawniono, że pacjenci podchodzą to tego pojęcia wielowymiarowo. Rozróżniają takie aspekty przyczyniające się do zaufania do lekarza, jak: kompetencja, wierność, uczciwość i troska [29].

Relacja lekarz-pacjent charakteryzuje się nierównowagą w zakresie wiedzy i władzy, którą dysponuje lekarz jako przedstawiciel systemu medycznego [31], zaś pacjent jej instytucjonalnie podlega. W tym kontekście niezbędne jest zwrócenie uwagi na potrzeby pacjenta. Podejście takie może niwelować stereotypy dotyczące postrzegania relacji lekarz-pacjent jako nazbyt zdominowanej przez perspektywę profesjonalną [32].

\section{Wpływ zaufania na zachowania i postawy w zdrowiu i chorobie}

Zaufanie do lekarzy i służby zdrowia związane jest z zachowaniami pro- lub antyzdrowotnymi, dostępem i korzystaniem z opieki zdrowotnej, przestrzeganiem zaleceń lekarskich oraz ciągłością leczenia. Zaufanie ma wpływ na podjęcie decyzji o rozpoczęciu leczenia. Thom i wsp. [33] potwierdzili, że osoby z niskim poziomem zaufania częściej zgłaszały przed wizytą, że nie jest im ona w ogóle potrzebna, także w przypadku wcześniejszego wskazania przez lekarza specjalistę zasadności takiej wizyty ze względu na poważny stan zdrowia chorego.

Liczne analizy potwierdziły również, że poziom zaufania do lekarza ma wpływ na ocenę jakości usług medycznych i zasadności stosowania procedur medycznych [34]. Thom i wsp. [33] w badaniach przeprowadzonych na próbie 732 dorosłych osób ze znacznym zagrożeniem zdrowia dowiedli, że pacjenci z niskim poziomem zaufania byli w mniejszym stopniu zadowoleni z opieki medycznej. Ponadto osoby o niższym poziomie zaufania do lekarza częściej zgłaszały, że nie są świadczone żądane lub potrzebne usługi [33], a także były mniej skłonne twierdzić, że oczekiwana lub potrzebna usługa medyczna została im udzielona. Pacjenci o niskim poziomie zaufania są też mniej skłonni do występowania o opinię drugiego specjalisty [10, 11]. Wysokie zaufanie do lekarza wpływa również pozytywnie na rekomendację specjalisty innym chorym [29].

Poziom zaufania do lekarzy związany jest również z poziomem satysfakcji z leczenia. Pacjenci z niskim poziomem zaufania są mniej zadowoleni z jakości opieki medycznej [10, 33, 35]; gorzej oceniają jakość relacji z lekarzem [36, 37, 38, 39]; gorzej oceniają poprawę swojego stanu zdrowia - np. w badaniu Thom 
i wsp. [33] rzadziej zgłaszali poprawę objawów w ciągu 2 tyg. Osoby z niskim poziomem zaufania do lekarza są słabiej zaangażowane w podejmowanie decyzji dotyczących leczenia [37]; częściej nie stosują się do zaleceń lekarskich [33] oraz rzadziej stwierdzano u nich poprawę objawów po 2 tyg. leczenia [33]. W badaniach przeprowadzonych przez Hillen i wsp. [14] na populacji 675 pacjentów onkologicznych potwierdzono korelacje między zaufaniem a satysfakcją z leczenia, chęcią polecania onkologa innym, zaufania do systemu opieki zdrowotnej oraz liczbą konsultacji z onkologiem. Przeprowadzone analizy wskazują na większe zaufanie wśród starszych pacjentów, którzy mają lepsze zdrowie psychiczne.

Jak pokazują przytoczone wyniki badań, wpływ zaufania do lekarza i medycyny ma wiele wymiarów, a szczególnego znaczenia nabiera ono w przypadku chorób nowotworowych. W związku z tak wysoką zachorowalnością i umieralnością na nowotwory wśród osób starszych interesującym zagadnieniem jest to, jakim poziomem zaufania odznaczają się właśnie seniorzy. Analiza literatury przedmiotu pokazuje, że brakuje rzetelnych i całościowych badań naukowych dotyczących osób starszych w kontekście problematyki onkologicznej $[2,40]$. Są one natomiast konieczne, jeżeli chce się planować i wdrażać skuteczne środki zapobiegania rozwojowi chorób nowotworowych w tej kategorii wiekowej, z uwzględnieniem potrzeb osób starszych oraz działając na rzecz optymalizacji jakości ich życia. Należy również pamiętać, że u seniorów prawie zawsze współwystępują dodatkowo inne związane z wiekiem choroby przewlekłe. W związku z tym zdecydowana większość seniorów ma duże doświadczenia, jeżeli chodzi o kontakt z przedstawicielami medycyny, co także rzutować może na poziom zaufania do lekarzy i medycyny. Stosunkowo niewiele analiz dotyczących chorób nowotworowych, a uwzględniających zmienną wieku, prowadzonych jest na próbie osób zdrowych [41, 42]. Warte podkreślenia są wyniki badań poświęconych chorobom nowotworowym, które pokazują, że osoby starsze, w tym po leczeniu onkologicznym, mają tendencję do: utożsamiania swoich problemów zdrowotnych z naturalnym procesem starzenia [43, 44]; traktowania objawów chorobowych jako czegoś nieuniknionego, nienadającego się do leczenia, a zatem nie wymagającego interwencji czy oceny medycznej [43, 44]; twierdzenia, że nowotwory są chorobami nieuleczalnymi [41]. W konsekwencji prowadzi to do powstania i utrwalenia biernej postawy w zdrowiu i chorobie $[42,45]$. Zaufanie do lekarzy i medycyny może być czynnikiem, który będzie pozytywnie motywował osoby starsze do podjęcia decyzji o zgłoszeniu się do lekarza w przypadku zaobserwowania niepokojących objawów i kontynuowania leczenia oraz stosowania się do zaleceń lekarskich, gdy zostanie postawiona diagnoza i wyznaczona metoda terapii.

W związku z tym przeprowadzono badanie socjologiczne wśród zdrowych osób starszych. Światowa Organizacja Zdrowia [46] stosuje następującą klasyfikację wieku starszego: wiek przedstarczy (45-59 lat), wczesna starość (60-74 lat), starość pośrednia (75-89 lat) i długowieczność (90+). W artykule przedstawiono wyniki dotyczące dwóch z sześciu kategorii stosowanych w analizach całej badanej populacji $(\mathrm{n}=910)-55-64$ lat i powyżej 65. r.ż. $(\mathrm{n}=329)$. Warto dodać, że wg Krajowego Rejestru Nowotworów w Polsce w latach 2011-2013 umieralność na raka drastycznie wzrasta właśnie w przedziale 55-59 lat, a najwyższa jest 60.-64. r.ż. oraz $65^{+}[47]$.

Celem badania była odpowiedź na następujące pytania badawcze:

1. Jaki jest poziom zaufania seniorów do lekarzy?

2. Jakie są przekonania osób starszych na temat efektywności medycyny w walce $\mathrm{z}$ chorobami nowotworowymi?

3. Jaki jest wpływ takich zmiennych społeczno-demograficznych, jak płeć, zamożność, samoocena sytuacji materialnej oraz wykształcenie na stopień zaufania seniorów do lekarzy oraz ich przekonania na temat efektywności medycyny w walce $\mathrm{z}$ chorobami nowotworowymi?

\section{MATERIAŁY I METODY}

Badania socjologiczne zrealizowano w okresie od marca do czerwca 2012 r. Przebadano 910 dorosłych mieszkańców Wrocławia w ramach działalności statutowej Zakładu Humanistycznych Nauk Lekarskich Uniwersytetu Medycznego im. Piastów Śląskich we Wrocławiu. Zastosowana została próba kwotowa (tab. 1). Populację generalną w badaniu stanowili dorośli mieszkańcy Wrocławia (2012 r.; n = 538 222). Dane dotyczące populacji generalnej zostały oszacowane przez Główny Urząd Statystyczny na podstawie wyników Narodowego Spisu Powszechnego Ludności i Mieszkań z 2011 r. Żeby zminimalizować niepewność danych oraz zapewnić wiarygodność próby, autorzy starali się zmaksymalizować jej podobieństwo do populacji generalnej, wybierając uczestników ze względu na cechy: płeć, wiek i poziom wykształcenia.

Jako metodę zastosowano wywiad kwestionariuszowy o wysokim poziomie standaryzacji, jako narzędzie badawcze - autorski kwestionariusz wywiadu. Badania miały charakter anonimowy.

Badano subiektywny (deklaratywny) poziom zaufania do lekarzy oraz subiektywny (deklaratywny) poziom identyfikacji respondentów z przekonaniami dotyczącymi efektywności medycyny w walce z chorobami nowotworowymi. Do oceny poziomu zaufania do lekarzy oraz przekonań - pkt 1 i 2 w celach badawczych (tab. 2) - zastosowano 4-stopniową skalę Likerta (tzw. skalę wymuszonego wyboru). Zastosowane w badaniu kategorie dotyczące wieku oraz wykształcenia zaprezentowano w tabeli 1.

Ze względu na szczególnie wysokie wskaźniki zachorowalności i umieralności na raka wśród osób starszych w artykule celowo pokazano tylko dane dla tej kategorii wiekowej (55-64 i $65^{+}$). Zilustrowano związek pomiędzy przekonaniami i zaufaniem do lekarza a takimi zmiennymi, jak: płeć, status ekonomiczny (w wymiarze obiektywnym - dochód oraz w wymiarze subiektywnym - samocena sytuacji materialnej) i wykształcenie badanych (tab. 3).

Zastosowano dostępne metody analizy danych jakościowych (categorical data analysis). W celu zbadania, czy istnieją 
TABELA 1. Porównanie populacji generalnej mieszkańców Wrocławia $(n=538222)$ oraz próby badawczej $(n=910)$

\begin{tabular}{|c|c|c|c|c|c|c|c|c|c|c|c|c|}
\hline \multicolumn{13}{|c|}{ Mężczyźni } \\
\hline Wiek & \multicolumn{2}{|c|}{$18-24$} & \multicolumn{2}{|c|}{$25-34$} & \multicolumn{2}{|c|}{$35-44$} & \multicolumn{2}{|c|}{$45-54$} & \multicolumn{2}{|c|}{$55-64$} & \multicolumn{2}{|c|}{$65+$} \\
\hline Wykształcenie & populacja & próba & populacja & próba & populacja & próba & populacja & próba & populacja & próba & populacja & próba \\
\hline wyższe & 0,005737 & 0,004396 & 0,050604 & 0,051648 & 0,026825 & 0,028571 & 0,017502 & 0,018681 & 0,018819 & 0,021978 & 0,019583 & 0,018681 \\
\hline średnie & 0,033562 & 0,037363 & 0,036386 & 0,034066 & 0,024882 & 0,024176 & 0,026357 & 0,024176 & 0,02935 & 0,02967 & 0,022491 & 0,021978 \\
\hline $\begin{array}{l}\text { podstawowe/ } \\
\text { zawodowe }\end{array}$ & 0,016073 & 0,016484 & 0,021199 & 0,01978 & 0,023292 & 0,021978 & 0,027201 & 0,026374 & 0,033445 & 0,02967 & 0,026052 & 0,02967 \\
\hline Wiek & \multicolumn{2}{|c|}{$18-24$} & \multicolumn{2}{|c|}{$25-34$} & \multicolumn{2}{|c|}{$35-44$} & \multicolumn{2}{|c|}{$45-54$} & \multicolumn{2}{|c|}{$55-64$} & \multicolumn{2}{|c|}{$65+$} \\
\hline Wykształcenie & populacja & próba & populacja & próba & populacja & próba & populacja & próba & populacja & próba & populacja & próba \\
\hline wyższe & 0,010908 & 0,013187 & 0,067608 & 0,067033 & 0,03377 & 0,035165 & 0,022649 & 0,026374 & 0,022528 & 0,023077 & 0,017352 & 0,017582 \\
\hline średnie & 0,034202 & 0,040659 & 0,026779 & 0,025275 & 0,025963 & 0,026374 & 0,036154 & 0,035165 & 0,049714 & 0,048352 & 0,045957 & 0,042857 \\
\hline $\begin{array}{l}\text { podstawowe/ } \\
\text { zawodowe }\end{array}$ & 0,012692 & 0,012088 & 0,01646 & 0,016484 & 0,016254 & 0,015385 & 0,020185 & 0,017582 & 0,028412 & 0,02967 & 0,053052 & 0,048352 \\
\hline
\end{tabular}

TABELA 2. Poziom zaufania do lekarzy oraz przekonania na temat efektywności medycyny w walce $\mathrm{z}$ chorobami nowotworowymi (n = 329)

\begin{tabular}{|c|c|c|c|c|}
\hline \multirow{2}{*}{$\begin{array}{l}\text { Zaufanie do lekarzy } \\
(\mathrm{n}=329)\end{array}$} & tak, bardzo duże & tak, duże & tak, małe & nie, nie mam zaufania \\
\hline & $28(8,51)$ & $146(44,38)$ & $89(27,05)$ & $66(20,06)$ \\
\hline $\begin{array}{l}\text { Przekonania na temat efektywności medycyny } \\
\text { w walce z chorobami nowotworowymi }(n=329)\end{array}$ & $\begin{array}{l}\text { całkowicie się } \\
\text { zgadzam }\end{array}$ & $\begin{array}{l}\text { raczej się } \\
\text { zgadzam }\end{array}$ & $\begin{array}{l}\text { raczej się } \\
\text { nie zgadzam }\end{array}$ & $\begin{array}{l}\text { całkowicie się } \\
\text { nie zgadzam }\end{array}$ \\
\hline $\begin{array}{l}\text { „Współczesna medycyna jest tak rozwinięta, } \\
\text { że skutecznie radzi sobie z leczeniem nowotworów” }\end{array}$ & $21(6,38)$ & $127(38,60)$ & $155(47,12)$ & $26(7,90)$ \\
\hline $\begin{array}{l}\text { „Współczesna medycyna zupełnie nie radzi sobie } \\
\text { z leczeniem nowotworów" }\end{array}$ & $13(3,95)$ & $79(24,01)$ & $176(53,50)$ & $61(18,54)$ \\
\hline
\end{tabular}

TABELA 3. Poziom zaufania do lekarzy oraz przekonań na temat efektywności medycyny w walce z chorobami nowotworowymi w zależności od płci, dochodu, samooceny sytuacji materialnej oraz poziomu wyksztatcenia $(n=329)$

\begin{tabular}{|c|c|c|c|c|}
\hline & Płeć & Dochód & $\begin{array}{c}\text { Samoocena sytuacji } \\
\text { materialnej }\end{array}$ & Wykształcenie \\
\hline Zaufanie do lekarzy & NS & $\begin{array}{l}X^{2}=22,29184 \\
p=0,03438 \\
\text { Cramér's V =0,1502846 }\end{array}$ & NS & $\begin{array}{l}X^{2}=18,66821 \\
p=0,01674 \\
\text { Cramér's V }=0,1684374\end{array}$ \\
\hline \multicolumn{5}{|c|}{ Przekonania na temat efektywności medycyny w walce z chorobami nowotworowymi } \\
\hline $\begin{array}{l}\text { „Współczesna medycyna jest tak } \\
\text { rozwinięta, że skutecznie radzi sobie } \\
\text { z leczeniem nowotworów" }\end{array}$ & NS & $\begin{array}{l}X^{2}=32,92862 \\
p=0,00099 \\
\text { Cramér's V =0,1826536 }\end{array}$ & $\begin{array}{l}X^{2}=24,13009 \\
p=0,00410 \\
\text { Cramér's V =0,1563583 }\end{array}$ & NS \\
\hline $\begin{array}{l}\text { „Współczesna medycyna zupełnie nie } \\
\text { radzi sobie z leczeniem nowotworów" }\end{array}$ & NS & NS & NS & NS \\
\hline
\end{tabular}

NS - nie stwierdzono

zależności pomiędzy poszczególnymi parami zmiennych kategorialnych (nominalnych lub porządkowych), obliczano wartość statystyki $\chi^{2}$. Siła zależności pomiędzy zmiennymi oceniana była na podstawie współczynnika V-Cramera (V). Wartości V kształtowały się na poziomie 0,1-0,3, co w przypadku prób losowych gwarantuje istotną zależność. Za istotne wyniki były przyjmowane takie, dla których p < 0,05. Ze względu na analizę zmiennych skategoryzowanych do oceny kierunku zależności zastosowano analizę korespondencji jako metodę wielowymiarowej analizy danych. Dane były analizowane przy użyciu programu Statistica v. 9.0.

\section{WYNIKI}

\section{Poziom zaufania do lekarza}

Większość badanych deklaruje zaufanie do lekarza, ale w różnym stopniu: 8,51\% ma bardzo duże zaufanie, $44,38 \%$ - duże, a 27,05\% - małe zaufanie. Natomiast 20,06\% respondentów nie ufa lekarzom (tab. 2).

Potwierdzono, że im wyższy poziom dochodów respondentów, tym wyższy poziom zaufania do lekarza $\left(\chi^{2}=22,29184\right.$; $\mathrm{p}=0,03438 ; \mathrm{V}=0,1502846)$ - tabela 3 . Na podstawie analizy korespondencji potwierdzono, że: osoby o dochodach w przedziale 901-1200 PLN częściej deklarują brak zaufania; respondenci o dochodach 1201-1500 PLN częściej odznaczają się małym zaufaniem; natomiast badani o najwyższych dochodach (powyżej 1500 PLN) częściej deklarują dość duże zaufanie do lekarzy. Zaufanie do lekarzy jest również zależne od poziomu wykształcenia seniorów $\left(\chi^{2}=18,66821 ; p=0,01674\right.$; $\mathrm{V}=0,1684374$ ). Potwierdzono, że osoby z wykształceniem średnim częściej deklarują bardzo duże zaufanie, natomiast badani z wykształceniem podstawowym/zawodowym częściej deklarują małe zaufanie do lekarzy (tab. 3). Nie potwierdzono zależności pomiędzy zaufaniem do lekarza a płcią oraz samooceną sytuacji materialnej respondentów. 


\section{Przekonania na temat efektywności medycyny w walce z chorobami nowotworowymi}

Prawie połowa respondentów $(44,98 \%)$ zgadza się ze stwierdzeniem, że „współczesna medycyna jest tak rozwinięta, że skutecznie radzi sobie z leczeniem nowotworów" (w tym 38,60\% raczej się zgadza, a 6,38\% całkowicie się zgadza). Natomiast $55,02 \%$ nie zgadza się z tym stwierdzeniem (w tym $47,12 \%$ raczej się nie zgadza, a 7,90\% całkowicie się nie zgadza) - tabela 2.

Istnieje zależność pomiędzy tym przekonaniem a wysokością dochodów badanych $\left(\chi^{2}=32,92862 ; \mathrm{p}=0,00099\right.$; $\mathrm{V}=0,1826536$ ) - tabela 3. Potwierdzono, że osoby najbiedniejsze częściej całkowicie się nie zgadzały ze stwierdzeniem, że „współczesna medycyna (...) skutecznie radzi sobie z leczeniem nowotworów", natomiast osoby dysponujące dochodem w wysokości 901-1200 PLN na osobę w rodzinie częściej raczej zgadzały się z tym stwierdzeniem.

Przekonanie, że „współczesna medycyna (...) skutecznie radzi sobie z leczeniem nowotworów", jest również zależne od samooceny sytuacji materialnej respondentów ( $\chi 2$ = 24,13009; $p=0,00410 ; \mathrm{V}=0,1563583)$. Osoby oceniające swoją sytuację materialną jako złą częściej całkowicie nie zgadzały się z tym przekonaniem. Nie potwierdzono zależności pomiędzy przekonaniem, że „współczesna medycyna (...) skutecznie radzi sobie z leczeniem nowotworów", a płcią i poziomem wykształcenia seniorów.

Kwestionariusz zawierał także stwierdzenie o charakterze kontrolnym: „współczesna medycyna zupełnie nie radzi sobie z leczeniem nowotworów". Odpowiedzi respondentów na to stwierdzenie były jeszcze bardziej korzystne w odniesieniu do terapeutycznych możliwości medycyny. Z tym stwierdzeniem nie zgodziło się 72,04\% badanych (w tym $53,50 \%$ raczej się nie zgadzało, zaś $18,54 \%$ całkowicie się nie zgadzało). Natomiast 27,96\% uznało, że stwierdzenie to jest prawdziwe (w tym 3,95\% całkowicie się zgadzało, a 24,01\% raczej się zgadzało) - tabela 2.

Nie potwierdzono zależności pomiędzy przekonaniem, że „współczesna medycyna zupełnie nie radzi sobie...”, a płcią, wysokością dochodów, samooceną sytuacji materialnej i poziomem wykształcenia badanych (tab. 3).

\section{DYSKUSJA}

Niewątpliwie społeczeństwo polskie ceni wysokie kwalifikacje i wykształcenie lekarzy [48, 49]. Interesującą kwestią wydaje się jednak to, czy za owym szacunkiem do zawodu lekarza idzie również zaufanie społeczne. Czy społeczeństwo ma poczucie bezpieczeństwa, że w sytuacji zagrożenia zdrowia - a w przypadku choroby nowotworowej także wysokiego zagrożenia życia - lekarz zrobi wszystko, by pomóc, wesprzeć chorego, czy wykorzysta cała swą wiedzę i doświadczenie na rzecz i dla dobra pacjenta? W badaniach CBOS [50], przeprowadzonych na reprezentatywnej próbie dorosłych Polaków, potwierdzono, że jedynie 16\% respondentów darzy lekarzy bardzo dużym zaufaniem. W porównaniu z pomiarami z lat 2007-2010 odnotowano nieznaczny wzrost zaufania do lekarzy. Blendon i wsp. [51] przeprowadzili analizę danych historycznych dotyczących zaufania publicznego do lekarzy w USA w latach 1966-2014 oraz 2011-2013. Dodatkowo dokonano analizy porównawczej danych z ostatnich lat dotyczących zaufania publicznego do lekarzy w 29 krajach uprzemysłowionych. Potwierdzono, że zaufanie publiczne do liderów medycyny w USA gwałtownie spadło w ciągu ostatniego półwiecza. W 1966 r. 73\% Amerykanów stwierdziło, że ma duże zaufanie do liderów zawodu medycznego, natomiast w 2012 r. tylko 34\%. Jednocześnie zaufanie do lekarzy pozostało jednak na wysokim poziomie, gdyż $65 \%$ badanych, biorąc pod uwagę uczciwość, darzy lekarzy jako grupę „bardzo wysokim” lub „wysokim” zaufaniem [52]. W 2014 r. zaufanie publiczne do amerykańskiego systemu opieki zdrowotnej było niewielkie, tylko $23 \%$ społeczeństwa miało duże lub bardzo duże zaufanie do systemu $[53,54]$. W badaniach Blendona i wsp. uwzględniona została również Polska. W odpowiedzi na stwierdzenie: „Biorąc wszystko pod uwagę, można zaufać lekarzom w twoim kraju", Polska znalazła się na ostatnim, 29. miejscu. Tylko 43\% respondentów stwierdziło, że stanowczo zgadza się lub zgadza się z tym stwierdzeniem. Uwzględniając sytuację ekonomiczną, zgadzało się z tym stwierdzeniem $41 \%$ osób o niskich dochodach oraz $47 \%$ respondentów o wyższych dochodach [51].

Zjawisko stopniowego spadku zaufania do zawodu lekarza obserwowane jest od lat 70. XX w. Medycynie zarzucano dysfunkcjonalność, nieprzystosowanie do potrzeb zdrowotnych społeczeństwa. Krytykowano ją m.in. za zbytnią koncentrację na leczeniu chorób, za zaniedbywanie profilaktyki, co w konsekwencji prowadziło do zbyt późnych interwencji medycznych, już w zaawansowanych stadiach chorobowych; koncentrację na biologicznych objawach i uwarunkowaniach choroby, z pominięciem czynników o charakterze psychospołecznym [55]. Opisywane przemiany uwidoczniły, że medycyna - pomimo dynamicznego rozwoju oraz ogromnych środków finansowych lokowanych na leczenie - ma stosunkowo niewielki, bo szacowany na ok. 10\% wpływ na zdrowie współczesnego człowieka. Kolejną poważną konsekwencją wspomnianych przemian jest potrzeba zmiany w relacjach pomiędzy lekarzem a pacjentem. Warto zwrócić uwagę, że choroby przewlekłe wiążą się z długim procesem leczenia. Poza tym w bardzo dużym zakresie są one konsekwencją prowadzenia przez jednostki i grupy niezdrowego stylu życia, a więc są w dużej mierze zależne od prozdrowotnych decyzji i wyborów jednostki, a nie tylko od czynników biologicznych czy genetycznych. W tym kontekście jednostka nie jest już tylko biernym odbiorcą świadczeń medycznych, lecz staje się odpowiedzialnym za siebie i swoje zdrowie podmiotem, który - również w związku z coraz wyższym poziomem wiedzy medycznej - chce mieć wpływ na proces leczenia i decydować o jego przebiegu. Wraz z radykalnym wzrostem nacisku na indywidualną kontrolę i wolność medyczny paternalizm nie otrzymuje już niekwestionowanej akceptacji przez społeczeństwo jako dominujący sposób podejmowania decyzji w opiece zdrowotnej [56]. Koniecznością staje się więc przejście od paternalizmu do partnerstwa w relacjach lekarz-pacjent. Postulowane jest odejście od tradycyjnych relacji terapeutycznych, w których osobą dominującą i posiadającą władzę nad chorym był lekarz. Relacja 
lekarz-pacjent ma nadal charakter asymetryczny, bowiem to lekarz dysponuje profesjonalną wiedzą i kompetencjami w zakresie medycyny, co daje mu instytucjonalnie przypisaną dominację nad pacjentem. Rozszerza się natomiast sfera autonomii pacjenta, zakres jego wpływu na przebieg procesu terapeutycznego. Pacjent jest $\mathrm{w}$ tej relacji podmiotem, a nie przedmiotem terapii, wspólnie z lekarzem podejmuje decyzje dotyczące leczenia i ponosi ich konsekwencje. Jak zauważa Tauber [57], poszanowanie autonomii pacjenta stało się częścią szerszej moralności relacji i opieki. Można to osiągnąć za pomocą upowszechnienia modelu partnerskiego współdziałania w podejmowaniu decyzji terapeutycznych [58]. Aby taki model skutecznie funkcjonował, niezbędne jest przywrócenie zaufania do relacji pomiędzy lekarzem a pacjentem oraz podejścia opartego na partnerstwie [56].

Poziom zaufania do lekarzy i medycyny jest zróżnicowany ze względu na zmienne społeczno-demograficzne, wyznaczające nierówności w sferze zdrowia. Jedną z tych zmiennych jest wiek. Jak pokazują badania, zależność pomiędzy poziomem zaufania a wiekiem wydaje się niejasna, na co może mieć wpływ specyficzna sytuacja społeczno-kulturowa badanych. Dla przykładu w polskich badaniach potwierdzono, że starsze osoby nieco rzadziej ufają innym w porównaniu z osobami młodszymi, ale mają lepsze zdanie o naturze człowieka - w większym stopniu zgadzają się z przekonaniem, że „ludzie przede wszystkim starają się służyć pomocą innym" [59]. Być może dlatego to właśnie najstarsi Polacy (powyżej 65. r.ż.) darzą stosunkowo dużym zaufaniem lekarzy [50]. Również w badaniach zachodnich potwierdzono wyższy poziom zaufania do lekarzy u osób starszych [11, $60,61]$. W analizowanym $\mathrm{w}$ niniejszym artykule badaniu nieco ponad połowa $(52,89 \%)$ starszych osób odznacza się znacznym poziomem zaufania do lekarzy. Warto natomiast zwrócić uwagę, że aż 20,06\% respondentów nie ma w ogóle, a 27,05\% ma bardzo małe zaufanie do lekarzy. Jeżeli chodzi o zaufanie do medycyny, ponad połowa badanych seniorów $(55,02 \%)$ nie zgadza się ze stwierdzeniem, że „współczesna medycyna (...) skutecznie radzi sobie z leczeniem nowotworów”, zaś w pytaniu kontrolnym - 27,96\% była przekonana, że „współczesna medycyna zupełnie nie radzi sobie z leczeniem nowotworów”.

Powyższe analizy zwracają uwagę na potrzebę intensyfikacji działań na rzecz zwiększenia poziomu zaufania seniorów do lekarzy i systemu medycznego w przypadku świadczenia usług onkologicznych. Ponadto istnieje kilka dodatkowych powodów przemawiających za tego rodzaju potrzebą. Po pierwsze, ze względu na to, że liczba zachorowań i zgonów na nowotwory rośnie z wiekiem; jest to grupa najczęściej korzystająca z tego rodzaju leczenia. Po drugie, osoby starsze odznaczają się wysokim poziomem lęku przed rakiem, w dużym stopniu przejawiają postawy fatalistyczne, a w konsekwencji przyjmują postawy bierne w chorobie.

Niezbędne są oczywiście działania prowadzone na poziomie makrostrukturalnym, mające na celu poprawę jakości i dostępności usług medycznych oraz alokację środków i zasobów na rzecz podnoszenia kompetencji medycznych, społecznych i komunikacyjnych personelu medycznego. Ponadto, ze względu na to, że zaufanie jest kluczowym elementem decydującym o efektywności terapeutycznej relacji lekarz-pacjent, niezbędnym jest również dostrzeżenie przez samych lekarzy potrzeby budowania zaufania wśród pacjentów w oparciu o poszanowanie ich autonomii, praw oraz partnerstwo, a także uwzględniając potrzeby emocjonalne osób korzystających ze świadczeń onkologicznych. W budowaniu zaufania osób starszych do lekarzy i medycyny pomocne mogą być również prowadzone przez instytucje i organizacje pozarządowe kampanie i programy ukierunkowane na szeroko rozumianą promocję zdrowia i profilaktykę onkologiczną [62].

Kolejną zmienną warunkującą poziom zaufania do lekarzy i medycyny jest płeć. Większym poziomem zaufania odznaczają się kobiety [61], jednakże w analizowanych w artykule badaniach nie potwierdzono tejże zależności.

Istotną zmienną, mającą wpływ na poziom zaufania respondentów zarówno do lekarzy, jak i medycyny, jest sytuacja ekonomiczna badanych. Warto pamiętać, że czynnik ekonomiczny jest jedną z najważniejszych zmiennych warunkujących nierówności w zdrowiu i chorobie. W wielu badaniach potwierdzono, że osoby o niższych dochodach mają ograniczone możliwości prowadzenia prozdrowotnego stylu życia; rzadziej szukają opieki zdrowotnej, a jeżeli szukają - to w nagłych wypadkach, w stanach ostrych [63], najrzadziej w celach profilaktycznych; odznaczają się gorszym zdrowiem, częściej zapadają na choroby przewlekłe [64], w tym nowotworowe [65], oraz wcześniej umierają [66]. Poza tym, im niższy status ekonomiczny jednostki, tym gorsza dostępność do usług medycznych oraz gorsza ich deklarowana jakość [63]. Respondenci o niskim dochodzie informowali o wyższym poziomie niezadowolenia $\mathrm{z}$ opieki zdrowotnej w porównaniu z respondentami o średnim poziomie dochodowości [67].

Badania potwierdzają, że pacjenci z niższych grup społeczno-ekonomicznych mają niższy poziom zaufania w porównaniu z pacjentami z wyższych grup społeczno-ekonomicznych [61]. Blendon i wsp. [51] również udowodnili, że większym zaufaniem darzą lekarzy Amerykanie o wysokich dochodach w porównaniu z respondentami o niskim statusie ekonomicznym. Ponadto, osoby o niskich dochodach były mniej zadowolone z leczenia w porównaniu $\mathrm{z}$ badanymi o wyższych dochodach (odpowiednio 48\% i 59\%).

W omawianym badaniu również potwierdzono, że osoby będące w gorszej sytuacji materialnej odznaczają się niższym poziomem zaufania. Zarówno obiektywny, jak i subiektywny wymiar sytuacji ekonomicznej miał wpływ na zaufanie pacjentów. Wysokość dochodu ma wpływ zarówno na poziom zaufania do lekarza, jak i na przekonania dotyczące możliwości medycyny w walce z chorobami nowotworowymi. Potwierdzono, że im niższe dochody badanych, tym mniejszy poziom zaufania do lekarzy, a także niższa zgodność z przekonaniem, że „współczesna medycyna (...) skutecznie radzi sobie z leczeniem nowotworów".

Jeżeli chodzi o subiektywny wymiar sytuacji materialnej, w przytaczanych wcześniej badaniach CBOS [50] potwierdzono, że relatywnie częściej bardziej krytyczni wobec lekarzy są respondenci niezadowoleni z własnej sytuacji ekonomicznej. W omawianych w niniejszym artykule badaniach również 
potwierdzono, że osoby oceniające swoją sytuację materialną jako złą częściej całkowicie nie zgadzały się z przekonaniem, że „współczesna medycyna (...) skutecznie radzi sobie z leczeniem nowotworów".

Ponadto personel medyczny powinien uświadamiać sobie znaczenie związku między poziomem wykształcenia a zdrowiem. Wykształcenie jest najważniejszą pojedynczą zmienną warunkującą zdrowie. W badaniach potwierdzono, że im wyższe wykształcenie, tym bardziej prozdrowotny styl życia [68]. W USA w momencie osiągnięcia dorosłości nierówności zdrowotne związane ze statusem społeczno-ekonomicznym są uderzające. W porównaniu z osobami, które mają wyższe wykształcenie, długość życia osób z niższym wykształceniem jest o 6 lat krótsza [69]. W odniesieniu do relacji lekarz-pacjent poziom wykształcenia wpływa na zdolność pacjenta do zrozumienia informacji diagnostycznych i zaleceń dotyczących leczenia [29].

Kierunek zależności pomiędzy wykształceniem a poziomem zaufania do lekarzy i medycyny nie jest jednoznaczny. Dla przykładu Balkrishnan i wsp. [11] oraz Kraetschmer i wsp. [60] potwierdzili, że wyższy poziom zaufania do lekarzy jest związany z niższym poziomem wykształcenia. Ten kierunek zależności potwierdzono również w badaniach na reprezentatywnej próbie dorosłych Polaków [50]: respondenci lepiej wykształceni rzadziej darzą lekarzy bardzo dużym zaufaniem, częściej zaś umiarkowanym. Natomiast przeciwny kierunek zależności odnotowano w badaniach Bonds i wsp. [61], w których okazało się, że niższym poziomem zaufania odznaczają się osoby z niższym wykształceniem. Taki sam kierunek zależności potwierdzono w omawianych w niniejszym artykule badaniach na osobach starszych.

Powyższe wyniki dotyczące wielowymiarowego wpływu statusu ekonomicznego oraz wykształceniem na zdrowie jednostek i grup zwracają uwagę na potrzebę kontynuacji strategii walki z nierównościami społecznymi w obszarze zdrowia, także w kontekście zaufania do lekarzy i medycyny. Utrudniony dostęp do instytucji medycznych oraz specjalistów w przypadku osób biedniejszych i gorzej wykształconych może negatywnie wpływać na poziom ich zaufania. Zrozumienie korelacji pomiędzy wykształceniem i dochodami a zagadnieniami związanymi ze zdrowiem, w tym z zaufaniem, może mieć również niebagatelne znaczenie w ustalaniu i realizowaniu priorytetów polityki zdrowotnej społeczeństwa. W miarę jak coraz większa uwaga skupiana jest na potrzebie rozwiązywania nierówności społecznych w celu niwelowania nierówności zdrowotnych, zrozumienie powiązań między różnymi zmiennymi społeczno-demograficznymi a zdrowiem staje się krytycznym wyzwaniem dla instytucji na wszystkich szczeblach zarządzania, które może przyczyniać się do poprawy polityki edukacyjnej. Budowanie zaufania społeczeństwa, w tym osób starszych, do lekarzy i medycyny, stanowi istotną strategię mającą na celu zwiększenie zaangażowania społeczeństwa w badania profilaktyczne i szybszą zgłaszalność do lekarza w przypadku zaobserwowania niepokojących objawów. To z kolei może przyczynić się do poprawy wskaźników wykrywalności nowotworów w początkowej fazie rozwoju, co zwiększa prawdopodobieństwo skutecznego ich leczenia.

\section{WNIOSKI}

Budowanie zaufania osób starszych do lekarzy i medycyny w przypadku chorób nowotworowych może przyczynić się do:

1. Poprawy oceny warunków leczenia i dostępności do onkologicznych usług medycznych. Jest to szczególnie istotne, gdyż ta niska ocena może dodatkowo potęgować bierność w zgłaszalności do lekarza w przypadku zaobserwowania niepokojących objawów oraz w kontynuowaniu leczenia w przypadku postawienia diagnozy nowotworowej.

2. Zwiększenia liczby osób wykonujących badania profilaktyczne, zgłaszających się do lekarza w krótkim czasie po wystąpieniu objawów. Czynniki te mają wpływ na wskaźniki wykrywalności nowotworów w początkowej fazie choroby, co zwiększa prawdopodobieństwo skutecznego ich leczenia, a także obniża koszty związane z terapią.

3. Zmniejszenia lęku pacjentów co do przedmiotowego traktowania przez personel medyczny.

4. Zwiększenia przekonania społeczeństwa na temat skuteczności medycyny w walce z nowotworami, co może przyczynić się do zwiększenia: wskaźników zgłaszalności na badania profilaktyczne; zgłaszalności do lekarza we wczesnych stadiach chorobowych; prawdopodobieństwa kontynuowania przez pacjenta leczenia i rehabilitacji w przypadku postawienia diagnozy nowotworowej.

\section{PIŚMIENNICTWO}

1. Yancik R, Ries LA. Cancer in older persons. Magnitude of the problem - how do we apply what we know? Cancer 1994;74(S7):19952003. doi: 10.1002/1097-0142(19941001)74:7+<1995:AID-CNCR 2820741702>3.0.CO;2-Y.

2. Yancik R, Ries LA. Cancer in older persons: an international issue in an aging world. Semin Oncol 2004;31(2):128-36. doi: 10.1053/j.seminoncol.2003.12.024.

3. Jemal A, Siegel R, Ward E, Hao Y, Xu J, Thun MJ. Cancer statistics, 2009. CA Cancer J Clin 2009;59(4):225-49. doi: 10.3322/caac.20006.

4. Wojciechowska U, Didkowska J. Zachorowania i zgony na nowotwory złośliwe w Polsce. Krajowy Rejestr Nowotworów, Centrum Onkologii Instytut im. Marii Skłodowskiej-Curie. http://onkologia.org.pl/raporty (30.12.2014).

5. European Commission EUROSTAT 2009. http://epp.eurostat.ec.europa. eu/statistics (29.10.2013).

6. Didkowska J, Wojciechowska U, Zatoński W. Prediction of cancer incidence and mortality in Poland up to the year 2025. Prognozy zachorowalności i umieralności na nowotwory złośliwe w Polsce do 2025. http://onkologia. org.pl/wp-content/uploads/Prognozy_2025.pdf (30.12.2014).

7. Reich M, Gaudron C, Penel N. When cancerophobia and denial lead to death. Palliat Suppor Care 2009;7(02):253-5. doi: 10.1017/S14789515090003.

8. Rabinowitz T, Peirson R. "Nothing is wrong, doctor": understanding and managing denial in patients with cancer. Cancer Invest 2006;24(1):68-76. doi: 10.1080/07357900500449678.

9. Tobiasz-Adamczyk B, Szafraniec K, Bajka J. Zachowania w chorobie: opis przebiegu choroby z perspektywy pacjenta. Kraków: Collegium Medicum Uniwersytetu Jagiellońskiego; 1999.

10. Hall MA, Zheng BY, Dugan E, Camacho F, Kidd KE, Mishra A, et al. Measuring patients' trust in their primary care providers. Med Care Res Rev 2002;59(3):293-318. doi: 10.1177/1077558702059003004.

11. Balkrishnan R, Dugan E, Camacho FT, Hall MA. Trust and satisfaction with physicians, insurers, and the medical profession. Med Care 2003;41(9):1058-64. doi:10.1097/01.MLR.0000083743.15238.9F. 
12. Salmon P, Young B. Dependence and caring in clinical communication: the relevance of attachment and other theories. Patient Educ Couns 2009;74(3):331-8. doi: 10.1016/j.pec.2008.12.011.

13. Seetharamu N, Iqbal U, Weiner JS. Determinants of trust in the patient oncologist relationship. Palliat Support Care 2007;5(4):405-9.

14. Hillen MA, Koning CC, Wilmink JW, Klinkenbijl JH, Eddes EH, KallimanisKing BL, et al. Assessing cancer patients' trust in their oncologist: development and validation of the Trust in Oncologist Scale (TiOS). Support Care Cancer 2012;20(8):1787-95. doi: 10.1007/s00520-011-1276-8.

15. Mechanic D, Meyer S. Concepts of trust among patients with serious illness. Soc Sci Med 2000;51(5):657-68.

16. Giddens A. Nowoczesność i tożsamość. Warszawa: PWN; 2012.

17. Giddens A. Konsekwencje nowoczesności. Kraków: Wyd. Uniwersytetu Jagiellońskiego; 2008.

18. Barber B. The logic and limits of trust. New Brunswick: Rutgers University Press; 1983.

19. Luhmann N. Trust and power. New York: Wiley; 1989.

20. Beck U, Giddens A, Lash S. Reflexive modernization: Politics, tradition and aesthetics in the modern social order. Stanford: Stanford University Press; 1994.

21. Calnan M, Rowe R. Trust Matters in Health Care. Maidenhead: Open University Press; 2008.

22. Goold SD, Klipp G. Managed care members talk about trust. Soc Sci Med 2002;54(6):879-88. doi: 10.1016/S0277-9536(01)00070-3.

23. Luhmann N. Familiarity, confidence, trust: problems and alternatives. In: Gambetta D, editor. Trust: Making and Breaking Cooperative Relations. Oxford: Blackwell; 1988.

24. Andreassen HK, Trondsen M, Kummervold PE, Gammon D, Hjortdahl P. Patients who use e-mediated communication with their doctor: new constructions of trust in the patient-doctor relationship. Qual Health Res 2006;16(2):238-48. doi: 10.1177/1049732305284667.

25. Meyer S, Ward P, Coveney J, Rogers W. Trust in the health system: an analysis and extension of the social theories of Giddens and Luhmann. Health Soc Rev 2008;17(2):177-86. doi: 10.5172/hesr.451.17.2.177.

26. Luhmann N. Trust and power: Two works by Niklas Luhmann. Brisbane: John Wiley and Sons; 1979.

27. Goudge J, Gilson L. How can trust be investigated? Drawing lessons from past experience. Soc Sci Med 2005;61:1439-51. doi: 10.1016/j.socscimed.2004.11.071.

28. McKinstry B, Ashcroft RE, Car J, Freeman GK, Sheikh A. Interventions for improving patients' trust in doctors and groups of doctors. Cochrane Database Syst Rev 2006;19(3):CD004134. doi:10.1002/14651858.CD004134. pub2.

29. Hall MA, Dugan E, Zheng B, Mishra AK. Trust in physicians and medical institutions: what is it, can it be measured, and does it matter? Milbank Q 2001;79(4):613-39. doi: 10.1111/1468-0009.00223.

30. Calnan M, Rowe R. Researching trust relations in health care: conceptual and methodological challenges - introduction. J Health Organ Manag 2006;20(5):349-58. doi: 10.1108/14777260610701759.

31. Bensing J. Bridging the gap. The separate worlds of evidence-based medicine and patient centered medicine. Patient Educ Couns 2000;39(1):17-25. doi: 10.1016/S0738-3991(99)00087-7.

32. Piątkowski W. Lecznictwo niemedyczne - perspektywa socjologiczna. In: Ostrowska A, editor. Socjologia medycyny. Podejmowane problemy, kategorie, analizy. Warszawa: Wyd. IFiS PAN; 2009. p. 311-38.

33. Thom DH, Kravitz RL, Bell RA, Krupat E, Azari R. Patient trust in the physician: relationships to patient requests. Family Practice 2002;19(5):47683. doi: 10.1093/fampra/19.5.476.

34. Lee YY, Lin JL. The effects of trust in physicians on self-efficacy, adherence and diabetes outcomes. Soc Sci Med 2009;68(6):1060-8. doi: 10.1016/j. socscimed.2008.12.033.

35. Pearson SD, Raeke LH. Patients' trust in physicians: many theories, few measures, and little data. J Gen Intern Med 2000;15(7):509-13. doi: 10.1046/j.1525-1497.2000.11002.x.

36. Tarrant C, Stokes T, Baker R. Factors associated with patients' trust in their general practitioner: A cross-sectional survey. Br J Gen Pract 2003;53(495):798-800.

37. Trachtenberg F, Dugan E, Hall MA. How patients' trust relates to their involvement in medical care. J Fam Pract 2005;54(4):344-52.
38. Safran DG, Taira DA, Rogers WH, Kosinski M, Ware JE, Tarlov AR. Linking primary care performance to outcomes of care. J Fam Pract 1998;47(3):213-20

39. O'Malley AS, Sheppard VB, Schwartz M, Mandelblatt J. The role of trust in use of preventive services among low-income African-American women. Prev Med 2004;38(6):777-85. doi: 10.1016/j.ypmed.2004.01.018.

40. von Wagner C, Macedo A, Campbell C, Simon AE, Wardle J, Hammersley $\mathrm{V}$, et al. Continuing cancer screening later in life: attitudes and intentions among older adults in England. Age Ageing 2013;42(6):770-5. doi: 10.1093/ageing/aft132.

41. Royer HR, Phelan CH, Heidrich SM. Older breast cancer survivors' symptom beliefs. Oncol Nurs Forum 2009;36(4):463-0. doi: 10.1188/09.0NF.463-470.

42. Ostrowska A. Profilaktyka zdrowotna: interpretacje, definicje sytuacji, racjonalności (przypadek profilaktyki ginekologicznej kobiet). Studia Socjologiczne 2011;3(202):73-94.

43. Heidrich SM, Egan JJ, Hengudomsub P, Randolph SM. Symptoms, symptom beliefs, and quality of life of older breast cancer survivors: A comparative study. Oncol Nurs Forum 2006;33(2):315-22. doi: 10.1188/06.0NF.315-322.

44. Morgan R, Pendleton N, Clague JE, Horan MA. Older people's perceptions about symptoms. Br J Gen Pract 1997;47(420):427-30.

45. Vos MS, De Haes JC. Denial in cancer patients, an explorative review. Psychooncology 2007;16(1):12-25.

46. WHO Center for Health Development. Ageing and Health Technical Report. http://www.who.int/kobe_centre/ageing/ahp_vol5_glossary.pdf?ua=1 (16.05.2016)

47. Nowotwory złośliwe ogółem. Krajowy Rejestr Nowotworów. 2017. http:// onkologia.org.pl/nowotwory-zlosliwe-ogolem-2 (16.05.2017).

48. Prestiż zawodów. Komunikat z badań BS/8/2009. CBOS. 2009. Warszawa: Fundacja Centrum Badania Opinii Społecznej; 2009.

49. Prestiż zawodów. Komunikat z badań BS/164/2013. CBOS. 2013. Warszawa: Fundacja Centrum Badania Opinii Społecznej; 2013.

50. Opinie o błędach medycznych i zaufaniu do lekarzy. Komunikat z badań nr 165/2014. CBOS. 2014. Warszawa: Fundacja Centrum Badania Opinii Społecznej; 2014.

51. Blendon RJ, Benson JM, Hero JO. Public trust in physicians - US medicine in international perspective. N Engl J Med 2014;371(17):1570-2. doi: 10.1056/NEJMp1407373.

52. Gallup Polls. Opinion Polls On Public Trust In Physicians. December 7-11, 2016. http://www.gallup.com/poll/1654/honesty-ethics-professions. aspx (21.04.2017).

53. Gallup Polls. Opinion Polls On Public Trust In Physicians. June 5-8, 2014. http://www.gallup.com/poll/171710/public-faith-congress-falls-againhits-historic-low.aspx (21.04.2017).

54. International Social Survey Programme Research Group. Health and Health Care - ISSP 2011. Cologne: GESIS Data Archive, 2013. ZA5800 Data file version 2.0.0. doi: 10.4232/1.11759.

55. Ostrowska A. Wstęp do socjologii medycyny. Warszawa: Wyd. IFiS PAN; 1990.

56. Chin JJ. Doctor-patient relationship: from medical paternalism to enhanced autonomy. Singapore Med J 2002;43(3):152-5.

57. Tauber AI. Sick autonomy. Perspect Biol Med 2003;46(4):484-95.

58. Smith M, Saunders R, Stuckhardt L, McGinnis JM, editors. Best Care at Lower Cost: The Path to Continuously Learning Health Care in America. Washington: National Academies Press; 2012.

59. Czapiński J, Panek T. Social diagnosis 2013. Objective and subjective quality of life in Poland. Warszawa: Rada Monitoringu Społecznego, 2013.

60. Kraetschmer N, Sharpe N, Urowitz S, Deber RB. How does trust affect patient preferences for participation in decision-making? Health Expect 2004;7(4):317-26. doi: 10.1111/j.1369-7625.2004.00296.x.

61. Bonds DE, Foley KL, Dugan E, Hall MA, Extrom P. An exploration of patients' trust in physicians in training. J Health Care Poor Underserved 2004;15(2):294-306.

62. Synowiec-Piłat M. Kampanie społeczne na rzecz pacjentów onkologicznych i ich najbliższych. Główne obszary działania. In: Synowiec-Piłat M, Olchowska-Kotala A, editors. Socjologia i psychologia dla pacjenta. Wybrane zagadnienia. Toruń: Wyd. Adam Marszałek; 2012.p. 66-83.

63. Fiscella K, Franks P, Gold MR, Clancy CM. Inequality in quality: addressing socioeconomic, racial, and ethnic disparities in health care. JAMA 2000;283(19):2579-84. doi: 10.1001/jama.283.19.2579.

64. Everson SA, Maty SC, Lynch JW, Kaplan GA. Epidemiologic evidence for the relation between socioeconomic status and depression, obesity, 
and diabetes. J Psychosom Res 2002;53(4):891-5. doi: 10.1016/S00223999(02)00303-3.

65. Gorey KM, Vena JE. The association of near poverty status with cancer incidence among black and white adults. J Community Health 1995;20(4):359-66.

66. Howard G, Anderson RT, Russell G, Howard VJ, Burke GL. Race, socioeconomic status, and cause-specific mortality. Ann Epidemiol 2000;10(4): 214-23. doi: 10.1016/S1047-2797(00)00038-7.

67. Becker G, Newsom E. Socioeconomic status and dissatisfaction with health care among chronically ill African Americans. Am J Public Health 2003;93(5):742-8.
68. Zimmerman EB, Woolf SH, Haley A. Understanding the relationship between education and health: a review of the evidence and an examination of community perspectives. Population health: behavioral and social science insights. Rockville: Agency for Health-care Research and Quality; 2015. p. 347-84. https://www.ahrq.gov/professionals/ education/curriculum-tools/population-health/zimmerman.html (21.04.2017).

69. Wong MD, Shapiro MF, Boscardin WJ, Ettner SL. Contribution of major diseases to disparities in mortality. N Engl J Med 2002;347:1585-92. doi: 10.1056/NEJMsa012979. 